\title{
The challenges of farmers' varieties of tef (eragrostis tef (zucc.) trotter) production and on farm conservation in North -West Amhara Region, Ethiopia
}

\begin{abstract}
A field survey was conducted during 2019 in four Administrative Zone, namely East and West Gojam, North and South Godar Zone of 12 woredas (District) in 16 Kebeles (the smallest administrative structure). The objectives of the study were to identify and evaluate the causes of genetic erosions and the degree of threatened varieties of tef. In addition, assessment conducted on the conservation and constraints of growing of farmers varieties of tef [Eragrostis tef (Zucc.) Trotter] in northwestern Amhara region has also the part of the study.During the surve 332 (male 313 and female 19) households were participated in the interview and group discussion and the reveal of the study was 35 farmers'varieties of tef, $30-50$ years old in the area were identified as under threatened; especially; in vernacular name or local language called Key tef (Dabo tef), Ancharo, Murie, Emblabish and Fesho were highly eroded.76.5\% factor for the erosion of land race of tef cultivar was introduction of improved varieties. And the second and the third causes for erosion of land race were Climate change and bad weather (drought, floods etc), logging problem \& introduction of improved varieties $9 \%$ and $4.8 \%$ respectively. Analysis of variance (ANOVA) was further computed using SPSS version 23 software. And practice and awareness on conservation of farmers' varieties didn't show any significant effect statistically $(\mathrm{p} \geq 0.05)$. However, factors that render for the erosion and identification of threatened farmer variety of tef at least 30-50 years old in the study area has show significant effect statistically $(\mathrm{p} \leq 0.05)$. Generally, farmers' varieties of tef have declined and some of them have disappeared. In situ conservation measures such as on farm planted of crops are very important methods for conserving local agrobiodiversity. Active community participation in integrated agrobiodiversity resource management, facilitation of innovative ideas of change agencies and favourable state policy support are essential elements in on-farm conservation and sustainable use. This conservation strategy should emphasize farmer's responsibility for the maintenance and sustainable utilization of diversity. Thus, in future I recommend that conservation of agro-biodiversity, sustainable protection measures based on local communities should be considered and adopted and develop packages for farmers' varieties and promoting awareness creation and on farm conservation practice in regular existing extension system.
\end{abstract}

Keywords: land race/farmers' varieties of tef, threatened, challenge, conservation
Volume 4 Issue 5 - 2020

\author{
Molla Abate \\ Crop and Horticulture Department, Ethiopian Biodiversity \\ Institute, Ethiopia
}

Correspondence: Molla Abate, Crop and Horticulture Department, Ethiopian Biodiversity Institute, Bahir Dar Center, Bahir Dar City, Ethiopia,

Emailmollaabate64@gmail.com, mollaabate79@yahoo.com

Received: May 07, 2020 | Published: October 08, 2020
Abbreviations: ANOVA, analysis of variance; $\mathrm{BC}$, before christ; BoA, bureau of agriculture; $\mathrm{CBD}$, convention on biological diversity; CSA, central statistical agency; $\mathrm{CV}$, coefficient of variation; EBI, ethiopian biodiversity institute; EC, ethiopian calendar; ETB, ethiopian birr; FAO, food and agricultural organization; GCV, genotoypic coffecient of variation; GDP, gross domestic product; HA, hectare; HHs, house holds; IBC, institute of biodiversity conservation; $\mathrm{KA}$, kebele adminstration; $\mathrm{Kg} /$ ha, kilogram per hectare; $\mathrm{Km}$, killo meter; M.a.sl, meter above sea level; PCV, phenotypic coffecient of variation; Qt/ha, quintal per hectare; SAS, statistical analysis software; SCV, simple coffecient of variation; SPSS, statistical package for the social sciences; SSR, simple sequence repeats; UNDP, united nation development program; WoRD \& A, woreda office of rural development and agriculture

\section{Introduction}

Agriculture is the basis of the Ethiopian economy accounting for $46 \%$ of Ethiopia GDP and $90 \%$ of its export earnings and employ
$85 \%$ of the countries labour force. ${ }^{1,2}$ Cereals including tef are the most important crops for human consumption. Tef is a superior cereal grain crop solely produced and is considered as the noble grain of Ethiopia.

Ethiopia is the center of origin and genetic diversity for many economically important crops including tef [Eragrostis tef (Zucc.) Trotter], noug [Guizotia abyssinica (L.f.) Cass], enset [Enset ventricosum (Welw) Cheeseman], coffee [Coffea arabica L.], chatt [Catha edulis (Vahl.) Forssk. ex Endl.], and Ethiopian mustard or gomenzer [Brassica carinata A. Braun]. ${ }^{3}$ In this regard, the varied agro-ecological and climatic condition of the country played a role and fosters cultivation of different crops species and varieties. ${ }^{4}$

Like all other cereal crops, tef belongs to the Poacea or Grass family and believed to be first domesticated by pre-Semitic inhabitants in Ethiopia between 4000 and 1000 B.C. The crop species is an allotetraploid believed to have originated from Eragrostis pilosa. ${ }^{5}$ It is also considered native to Northern Ethiopia, although so far only five wild types or accessions were collected from only the lowlands in the 
North East and South East Ethiopia. ${ }^{6}$ In the genus Eragrostis, there are about 350 species in the tropical and subtropical regions. ${ }^{7}$ Among these, 54 species are found in Ethiopia from which 14 are endemic. However, attempts have not so far been to collect and conserve them. Tef is the only cultivated species in this genus Eragrostis, and together with finger millet (Eleusine crocana L.), they are the only two species in the sub-family Chloridoidae that are cultivated for human consumption of the grains.

Tef is the major food crop in Ethiopia where it is annually cultivated on more than three million hectares of land. ${ }^{8}$ The major tef producing areas are found within Oromiya and Amhara Regional States. It is widely grown in both high-potential and marginal production areas. These areas include most parts of the vertisols that suffer from water logging and other non-vertisol parts of the country that suffer from low-moisture stress. ${ }^{9}$

Compared to other cereals, tef is more tolerant to extreme environmental conditions especially to water logging. It is unique in its ability to grow and yield on poorly drained Vertisols, which most cereals cannot tolerate. Unlike other cereals, the seeds of tef can be easily stored under local storage conditions without losing viability since the grains are resistant to attack by storage pests. ${ }^{10}$ Tef grain is also a rich source of protein and nutrients and has additional health benefits including that the seeds are free from gluten. ${ }^{11}$ According to a recent study, the bio-available iron content was significantly higher in tef bread than in wheat bread. ${ }^{12}$ In general, tef provides quality food and grows under marginal conditions, many of which are poorly suited to other cereals.

In the earlier time most of the Ethiopian farmers use traditional landraces of tef and these are distributed all over the country. Local cultivars such as "Gea-Lamie, Dabi, Shewa-Gimira, Beten and Bunign", which are early maturing varieties ( $<85$ days), are widely used in areas that have a short growing period due to low moisture stress or low temperature.

The same varieties are also used in areas with adequate rainfall and where double cropping is practiced. In the highly productive and major tef-producing regions of Gojam and Shewa, and in other regions where environmental stress is not severe, the local cultivars such as "Alba, Ada and Enatit", etc is used. Modem varieties are used in many regions but in very small areas within each region. In the previous administration zonal of Gojam and Shewa, which are located in the central highlands of Ethiopia and are also the largest and major tef production areas in the country modern varieties are used as well as traditional landraces and local cultivars. ${ }^{10}$

These Farmers' varieties/landraces of tef and others are domesticated agricultural plant species which has adapted to the local natural environment in which it lives for long period of time. Local varieties are crop species developed by natural processes adapting both the natural and cultural environments in a given landscape. This practices favors co-evolution that would eventually produce drought and disease resistance species and varieties unlike off-farm (Ex-situ) conservation in formal seed banks and greenhouses.

However, currently, local crop varieties/farmers' varieties are under extraordinary phases of erosions. Studies showed that over $75 \%$ of the genetic diversity of agricultural crops is lost over the last two decades with 100 to 1000 folds decrease overtime. ${ }^{13}$ In this regard, the intensification, specialization and mechanization of agricultural production lose of habitats through climatic and socio-economic changes play the leading role to the loss of landraces. ${ }^{14,15}$
Tef represents a unique biodiversity component in the agriculture and food security systems of millions of poor farmers in Ethiopia. It possesses excellent adaptation to drought and poor soils, providing a reliable harvest under such conditions, growing where most crops do not succeed, and providing good nutritional sources. However, the crop suffers neglect in science despite increasing awareness of plant genetic resource conservation and local food security concerns. ${ }^{16}$ Conservation and production of such species have high economical importance towards improvement of the livelihoods of the smallholder farmers in Ethiopia in general and in Amhara region in particularly.

Absences of prepared and updated list of National tef varieties including vernacular name and description of their morphology at national level makes this study very difficult. It is very important the availability of list of updated National tef varieties (improved and land race) with the description of their morphology and vernacular name will help us to avoid redundant and ease identification process of red list and the extinct farmers' varieties in the time of survey or inventory time easily.

Therefore this study was conducted to identify the current challenges for production and on farm conservation of farmers' varieties of tef in North West Amhara region for the following objectives.

\section{General objective}

The general objective of the survey is to evaluate and identify the causes of genetic erosion and challenges of on farm conservation of threatened/endangered farmers' varieties of tef.

\section{The specific objectives are indeed:}

i. To evaluate the degree of threatened and constraints of growing of farmers' varieties of tef in the study area.

ii. To identify the causes of genetic erosions of farmers varieties of tef [Eragrostis tef (Zucc.) Trotter] in northwestern Amhara region;

\section{Methods}

The study was conducted in four Zonal Administration namely East Gojam, West Gojam, North Gondar and South Gondar in 12 Woredas (Districts) of Northwest Amhara Regional State, Ethiopia. The selections of a study area were based on annual report of Bureau of Agriculture (BoA), Zonal and woreda offices of Agriculture (WoA) on their potential of tef producting.

From each woreda 1-2 kebeles (the smallest administration structure of government) were selected for the study purpose. The study areas have 79 villages, and out of these 16 villages were selected randomly. According to 2017 Central Statistics Agency (CSA) ${ }^{17}$ population projection data report; a total household's number of 16 villages of the survey area were 7747 and from these 1669 households have $\geq 0.5$ hectare land size. These make them a good experience in growing of tef in their farm. For our interview and group discussion purpose we selected 332 household heads of respondents which have $\geq 0.5$ hectare land size using purposive sampling methods. As shown in (Table1) these 332 samples of the selected kebeles (KAs) were distributed proportionally for household survey using the following formula:

Sample size $=\mathrm{n}=(100-\mathrm{p})^{2} / \mathrm{e}^{2}$

Where:

$\mathrm{N}=1669$ 
$\mathrm{Z}$ score $=1.96$ for confidence level $95 \%$

Proportion $\mathrm{P}$ is the expected outcome $(50 \%)$

$5 \%$ margin of error and $95 \%$ confidence level were used.

Calculating the right sample size is crucial to gaining accurate information.

In fact, a survey's confidence level and margin of error almost solely depends on the number of responses what we received. In the Survey Sample Size Calculator, we know that a sample size of 332 people gives us a confidence level of $95 \%$ with a margin of error of $5 \%$. Our $95 \%$ confidence level states that 19 out of 20 times we conduct this survey our results would land within our margin of error. Our 5\% margin of error says that if we surveyed all 1669 subscribers, the results could differ with a score of minus $5 \%$ or plus $5 \%$ from its original score. And here are the formulas used to calculate sample size:

\section{Sample Size calculation:}

Sample Size $=($ Distribution of $50 \%) /(($ Margin of Error $\% /$ Confidence Level Score)Squared)

\section{Finite population correction:}

True Sample $=($ Sample Size X Population $) /($ Sample Size + Population - 1)
Therefore our sample size was determined by the following calculation.

i. Sample Size $=(0.5 \times(1-0.5)) /((0.05 / 1.96)$ Squared $)$ Sample Size $=0.25 /((0.02551 \ldots)$ Squared $)$ Sample Size $=0.25 /$ $0.00065077 \ldots$ Sample Size $=384.16 \ldots$

ii. True Sample $=384.16 \ldots \times 1669 / 384.16 \ldots+1669-1$ True Sample $=641163.04 \ldots / 2052.16$ True Sample $=312.43326 \ldots=313$ and true sample size were 332 which was more than the expected sample size which makes the study on the safest way.

\section{Description of the study area}

The survey area covered four zonal administrations namely, East Gojam (four woredas), West Gojam (two woredas), North Gondar (three woredas) and South Gondar (three woredas). The study area is located the nearest $40 \mathrm{~km}$ and the distant $350 \mathrm{~km}$ from Bahir Dar capital city of Amhara Regional State. And the longitude, latitude and altitude (see Appendix 4).

The mean annual temperature of the survey area has been reported between $18.5^{\circ} \mathrm{C}$ with $10^{\circ} \mathrm{C}$ and $31^{\circ} \mathrm{C}$ minimum and maximum temperatures (source WoRA). In addition the survey site receives on average total rainfall between $1000-1400 \mathrm{~mm}$ annually with Meher (main) rain season occurring from May to September, mainly June, July and August (WoRA, year 2018/19 Annual report).

Table I Distribution of the sample households by woreda and kebeles

\begin{tabular}{|c|c|c|c|c|c|}
\hline Zone & Woredas & $\begin{array}{l}\text { Name of selected } \\
\text { Kebeles (KAs) }\end{array}$ & $\begin{array}{l}\text { Total HHs } \\
\text { number of KAs }\end{array}$ & $\begin{array}{l}\text { HH'sholding } \geq 0.5 \mathrm{ha} \\
\text { land size }\end{array}$ & $\begin{array}{l}\text { Number of selected } \\
\mathrm{HHs}\end{array}$ \\
\hline \multirow{3}{*}{ West Gojam } & Yilmanadenssa & Kililt & 636 & 155 & 30 \\
\hline & North Achefer & Denbola & 443 & 108 & 21 \\
\hline & & Liben Dankura & 418 & 102 & 19 \\
\hline \multirow[t]{3}{*}{ South Godar } & Farta & Hiruy Abaregay & 526 & 55 & 11 \\
\hline & Estie & Dengolit & 454 & 62 & 13 \\
\hline & Simada & Yekuasa Abo & 500 & 122 & 25 \\
\hline \multirow[t]{4}{*}{ East Gojam } & Dejen & Yetnora & 508 & 75 & 15 \\
\hline & Shebel Berenta & Geda Eyasu & 520 & 78 & 15 \\
\hline & Enemay & Kidisge & 491 & 71 & 15 \\
\hline & Aneded & Jama & 584 & 240 & 48 \\
\hline \multirow[t]{6}{*}{ Central Godar } & Takussa & Mekonta & 490 & 95 & 20 \\
\hline & & Chanka & 495 & 96 & 20 \\
\hline & Chilga & Teber Serako & 447 & 109 & 20 \\
\hline & & Eyaho & 455 & 111 & 20 \\
\hline & Lay Armachiho & Lomiyena kechaynetwuha & 398 & 97 & 21 \\
\hline & & Shumara & 382 & 93 & 19 \\
\hline Total & 12 & 16 & 7747 & 1669 & 332 \\
\hline
\end{tabular}




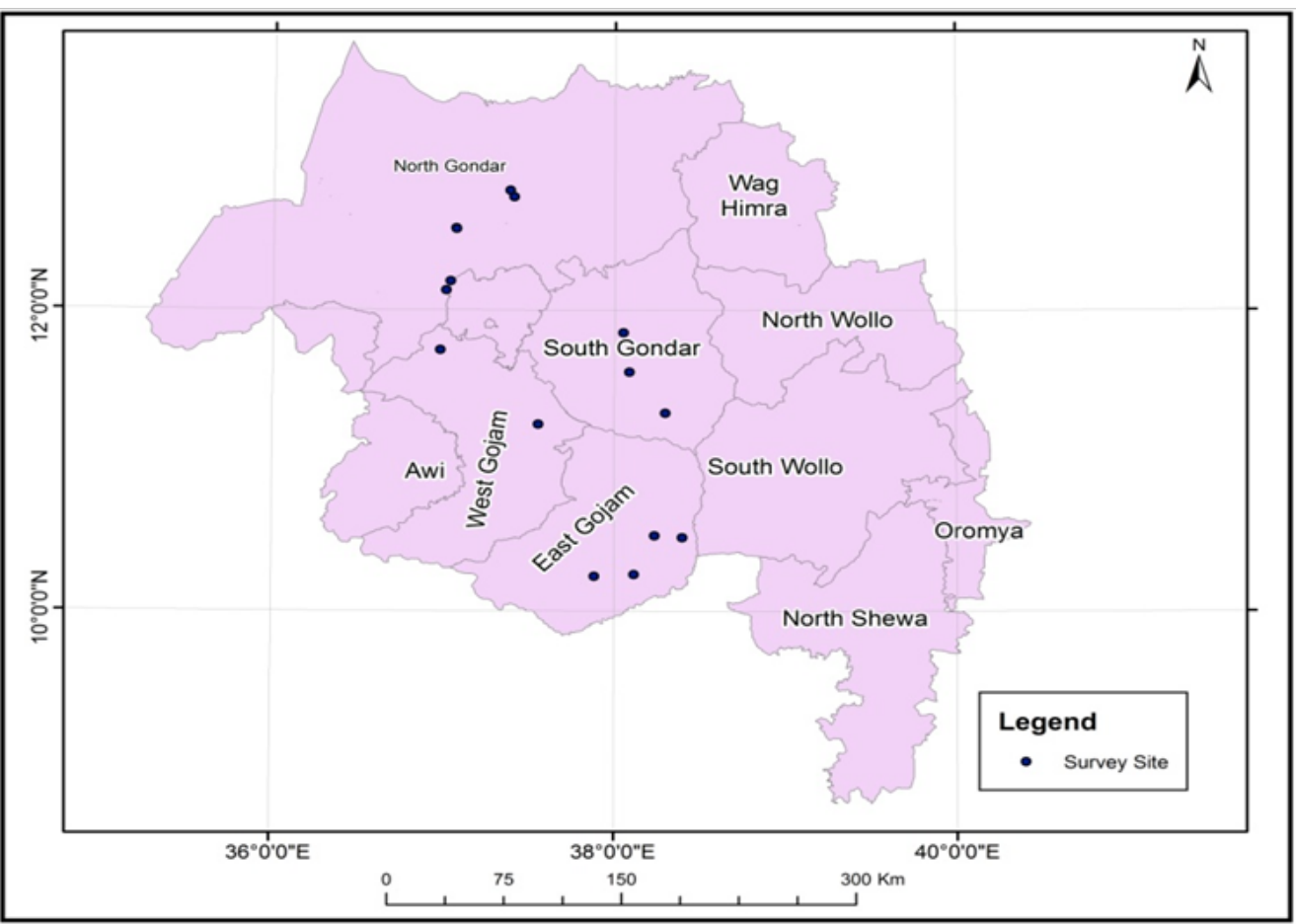

Figure I Map of the survey area in Amhara Region.

\section{Data collection}

Both quantitative and qualitative data were collected to identify the main case for the erosion of farmer's varieties (land race) of tef and the challenge of on farm conservation and growing of farmers' varieties in the study area. A qualitative data was collected using structured and semi-structured questioners (see the appendix), focus group discussion and key informant interviewed which was prepared as recommended. ${ }^{18,19}$ Furthermore, some relative secondary data were considered to strengthen the study used from the annual reports of offices of agriculture and related published and unpublished articles.

The socio- economic impacts are highly influenced by the demographic, social and economic characteristics of the smallholder households. The sub-section, therefore, provides baseline information on the demographic and socio-economic of the 332 respondent small holder tef producing farmers, under which the main findings are manifested. During the study wide ranges of information on demographic and socio-economic determinants such as age, sex, marital status, landholding size, etc have been collected.

\section{Socio economic of the study area}

\section{Age, sex composition and marital status of the selected households}

Sex composition of the respondents enables us to show the proportion of male and female headed tef producing farmers in the study area. The survey result revealed that the majority household heads were male headed $313(94.3 \%)$ while about 19 (5.7\%) of tef producing farmers were female headed (Table 2). This shows that female headed households living in rural area is very few in number than male headed households.

In the other age distribution of respondent household heads was $68.6 \%$ above 41 years old. This could imply that understanding of the farming environment, farmers' varieties of tef, land management and other farming practice are more experienced and would be high as agricultural activities. The very amazing point is many of aged farmers in the study area were adopted new technology of improved seed at large in their farm land.

It is also evident from (Table 2) that about $96.4 \%$ of respondents were married, $0.6 \%$ singled, $1.5 \%$ divorced, $0.9 \%$ widowed and $0.6 \%$ widower. The results of the present study clearly showed that many of the farmers in the study area were married and give birth at the early ages which may cause high population density that imposes greater pressure on the utilization of natural resource in the study area.

\section{Education and land holding size}

Education would have a great influence on farmers' awareness towards varieties of environmental issues and ultimately to associate challenging agro biodiversity declining or deterioration with the farming practices. Therefore, respondents were asked about their educational qualification. The results revealed that the majority of household heads did not attend formal education. The percent of household heads that attended school above primary education was $4.8 \%$. According to the survey result $34.3 \%$ of the respondents were illiterate and $60.8 \%$ of them attended in non-formal education (can only read and write). These group of respondents attended either church or adult education. Surprisingly, only $3(0.9 \%)$ of the respondents attended secondary education, and most probably these household heads enhance the conservation and restoration of land race tef varieties. Therefore, it is very important to build up useful changes in the attitudes, beliefs and habits of the farmers to improve the willing in conservation of farmers' varieties.

The average number of persons reside within particular area of respondents is described by households' land size. According to Shanin, ${ }^{20}$ "Land acts as an entrance ticket into the peasantry ..." Therefore, it is difficult to think a farmer without land. Similarly 
respondents of the study area have their own land holding. But, a fixed area of arable land was divided among many farmers in the study area within the historical land distribution of year 1997.

According to a survey results, more than $82 \%$ of the respondents have their own farm land managed 0.5-1.5 hectares for growing of

Table 2 Household's socio demographic data of the study area

\begin{tabular}{|c|c|c|c|c|c|}
\hline Variable & Category & Frequency & Percent & Valid percent & Cumulative percent \\
\hline \multirow[t]{6}{*}{ Educational level } & Illiterate & 114 & 34.3 & 34.3 & 34.3 \\
\hline & Read and write only & 202 & 60.8 & 60.8 & 95.2 \\
\hline & Primary school & 11 & 3.3 & 3.3 & 98.5 \\
\hline & Junior school & 2 & 0.6 & 0.6 & 99.1 \\
\hline & Secondary school & 3 & 0.9 & 0.9 & 100 \\
\hline & Total & 332 & 100 & 100 & \\
\hline \multirow[t]{7}{*}{ Marital status } & Single & 2 & 0.6 & 0.6 & 0.6 \\
\hline & Married & 320 & 96.4 & 96.4 & 97 \\
\hline & Divorced & 5 & 1.5 & 1.5 & 98.5 \\
\hline & Widowed & 3 & 0.9 & 0.9 & 99.4 \\
\hline & Widower & 2 & 0.6 & 0.6 & 100 \\
\hline & Total & 332 & 100 & 100 & \\
\hline & Female & 19 & 5.7 & 5.7 & 5.7 \\
\hline \multirow[t]{2}{*}{ Sex } & Male & 313 & 94.3 & 94.3 & 100 \\
\hline & Total & 100 & 100 & 100 & \\
\hline \multirow[t]{6}{*}{ Land holding size } & $\geq 0.5 \mathrm{I}-\mathrm{Iha}$ & 193 & 58.1 & 58.1 & 58.1 \\
\hline & I.I-I.5ha & 80 & 24 & 24 & 82.2 \\
\hline & I.5I-2ha & 35 & 10.5 & 10.5 & 92.8 \\
\hline & 2.l-3ha & 18 & 5.4 & 5.4 & 98.2 \\
\hline & $>3$. Iha & 6 & 1.8 & 1.8 & 100 \\
\hline & Total & 332 & 100 & 100 & \\
\hline \multirow[t]{5}{*}{ Age } & $21-30$ & 11 & 3.3 & 3.3 & 3.3 \\
\hline & $31-40$ & 93 & 28 & 28 & 31.3 \\
\hline & $4 \mid-50$ & 114 & 34.3 & 34.3 & 65.7 \\
\hline & $\geq 51$ & 114 & 34.3 & 34.3 & 100 \\
\hline & Total & 332 & 100 & 100 & \\
\hline
\end{tabular}

Source: field survey 2019.

\section{Data analysis}

Data was analyzed using descriptive statistics such as frequency, mean tables, figures and others were employed for most of the qualitative data collected. For quantitative data analysis we used SPSS version 23 at $5 \%$ probability level based on the results.

Correlation analysis was also carried out to study the nature and degree of relationship between the factors and at least 30-50 years old farmers' varieties in the area as influenced. Correlation coefficient values (r) were calculated and test of significance was analyzed using Pearson correlation procedure found in SPSS version 23 software.

Pearson correlation method was selected since it is widely used in the sciences as measure of the degree of linear dependence between two variables. It measures the strength of the linear relationship between normally distributed variables. In statistics the person correlation coefficient is a measure of the linear correlation between different crops, indicating a preponderance of smallholder farmers. Therefore all these synergy and experience shows that respondents can able to have enough information about land race/ farmers' varieties of tef in the area. 
a. The influence of invasive alien plant species,

b. Climate change and bad weather or hazards (drought, floods etc),

c. Farming/cultivation systems,

d. Introduction of improved varieties,

e. Logging problem \& introduction of improved varieties,

f. Introduction of improved varieties and other factors (weed. Pest, disease...),

g. Farming/cultivation system and logging problem, h. Reduction of productivity \& introduction of improved varieties and

i. Reduction of productivity was discussed

\section{The challenge of farmers' varieties (land race) of Tef}

Descriptive statistical values for the analysis of assessment of threatened farmer variety of tef at least 30-50 years old in the area, the effect of factors that render for the erosion/loss of these varieties, the identified threatened farmers' variety of tef at least 30-50 years old in the area and farmers awareness and on farm conservation practice of land race of tef; respondent's results were presented in the (Table 3 ).

Table 3 Descriptive statistical values

\begin{tabular}{|c|c|c|c|c|c|c|c|c|c|}
\hline Character & Min. & Max & Mea. & Med. & Mod. & SD & SE & Skewness & Sign. \\
\hline $\begin{array}{l}\text { Listed threatened farmers' variety of tef at least } \\
30-50 \text { years old in the area }\end{array}$ & 0 & 42 & 30.31 & 34 & 31 & II.497 & 0.631 & -1.272 & $* *$ \\
\hline Factors that render for the erosion & 0 & 10 & 3.17 & 3 & 3 & 1.61 & 0.088 & 2.148 & $* *$ \\
\hline \multicolumn{10}{|l|}{ /loss of these varieties } \\
\hline $\begin{array}{l}\text { Is there threatened Farmer variety of tef at } \\
\text { least } 30-50 \text { years old in the area }\end{array}$ & $\mathrm{I}$ & 2 & 1.006 & I & $\mathrm{I}$ & 0.0775 & 0.004 & 12.825 & $* *$ \\
\hline $\begin{array}{l}\text { Do you have any practice or get awareness to } \\
\text { conserve land race of tef on your farm }\end{array}$ & 1 & 2 & 1.96 & 2 & 2 & 0.1943 & 0.01 & -4.773 & ns \\
\hline
\end{tabular}

Indicates significance at $* * \mathrm{p}<0.00 \mathrm{I},{ }^{*} \mathrm{p}<0.05$ probability level, ns indicates non significance. $* *=$ highly significant, $*=$ significant, ns $=$ non- significant

The current situation of $\mathbf{3 0 - 5 0}$ years old land race of Tef

The results and major findings of this study conducted to determine the existing condition of 30-50 years old cultivated farmers' varieties (land race) of tef. The result of this study on the current situation of farmers' varieties of tef was 330's (99.4\%) of respondents were responded, 30-50 years old farmers' varieties (land race) of tef is seriously under threatened in the study area and the result presented in (Table 4) (Figure 2).

Table 4 Responds' of participants on the threatened of land race of tef in the area

\begin{tabular}{llllll}
\hline Variable & Category & Frequency & Percent & Valid percent & Cumulative percent \\
\hline $\begin{array}{l}\text { At least 30-50 years old farmers' varieties of tef in } \\
\text { the area are threatened }\end{array}$ & Yes & 330 & 99.4 & 99.4 & 99.4 \\
& No & 2 & 0.6 & 0.6 & 100 \\
\hline
\end{tabular}

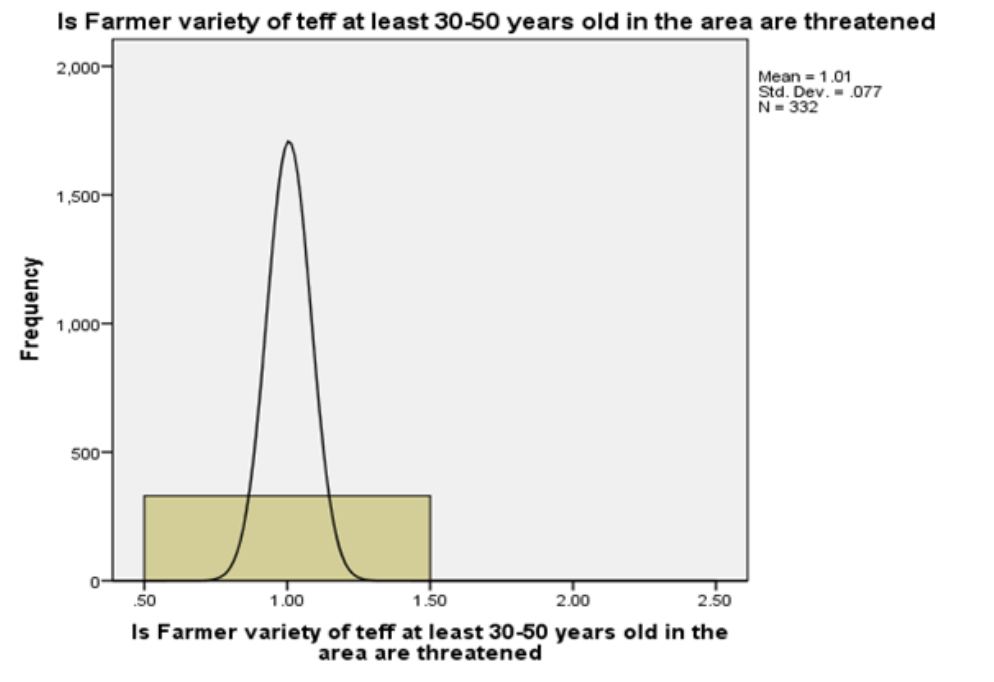

Figure 2 Graphic presentation of participants responded on incidence of threatened land race tef variety. 
As the study revealed a reason for the erosion were the influences of introduction of improved varieties, invasive alien plant species, climate change, shift of farming/cultivation systems, logging problem and reduction of productivity.

These findings are in agreement with the report indicated currently, local crop varieties/farmers' varieties are under extraordinary phases of erosion. Over $75 \%$ of the genetic diversity of agricultural crops is lost over the last two decades with 100 to 1000 folds decrease overtime, due to the intensification, specialization and mechanization of agricultural production lose of habitats through climatic and socioeconomic changes play the leading role to the loss of Landraces. ${ }^{14,15}$

Study showed that, the important of traditional knowledge and should be preserved, as in many cases the oral transmission of local knowledge between elder and young generations is not always officially supported. ${ }^{21}$

There is also the same study Land race/farmers varieties are replaced by improved varieties could determine the existing condition of 30-50 years old cultivated farmers' varieties (land race) of tef and associated traditional knowledge related to crops, agricultural systems and practices, weeds, pests, invasive alien species, water management, land use and also the biodiversity behind agrobiodiversity, with multiple dimensions. ${ }^{22,23}$ The oral transmission of local knowledge between elder and young generations is not always officially supported. ${ }^{21}$ Once crop erosion results from local socioeconomic vulnerabilities, the crop-associated knowledge is also lost. The result of the study on the current situation of farmers' varieties of tef is presented (Table 4).

Statistically the analysis of variance on farmers' variety of tef at least 30-50 years old in the area shows that they are affected significantly $(p<0.05)$ see $($ Table 5$)$. Even through the skewness is positive, the statistics in (Table 3) indicated that the extent of score distribution almost nearest to perfect symmetry (mean=1.006, median $=1.00$ and $\operatorname{mode}=1.00$ ).

Based on the significance of the ANOVA, test of significance difference of mean values of 35 listed threatened farmers' variety of tef at least 30-50 years old in the area was employed (Table 6). It was observed that varieties were significantly $(\mathrm{p}<0.05)$ different between and within group from each other.

Table 5 ANOVA of Farmers' variety of tef at least 30-50 years old in the area threatened

\begin{tabular}{|c|c|c|c|c|c|c|c|}
\hline & & & Sum of Squares & Df & Mean Square & $\mathbf{F}$ & Sig. \\
\hline \multirow[t]{3}{*}{ Between Groups } & (Combined) & & 4584.533 & 9 & 509.393 & 4.188 & $* *$ \\
\hline & Linear Term & Weighted & 2467.163 & 1 & 2467.163 & 20.282 & $* *$ \\
\hline & & Deviation & 2117.37 & 8 & 264.671 & 2.176 & $*$ \\
\hline Within Groups & & & 39168.129 & 322 & 121.64 & & \\
\hline Total & & & 43752.663 & 331 & & & \\
\hline
\end{tabular}

Indicates significance at $* * p<0.001, * p<0.05$ probability level, ns indicates non significance. $* *=$ highly significant, $*=$ significant, ns $=$ non- significant

Table 6 Anova of list of threatened farmers' variety of tef at least 30-50 years old in the area

\begin{tabular}{llllll}
\hline & Sum of Squares & df & Mean Square & F & Sig. \\
\hline Between Groups & 4584.533 & 9 & 509.393 & 4.188 & \\
Within Groups & 39168.129 & 322 & 121.64 & & \\
Total & 43752.663 & 331 & & & \\
\hline
\end{tabular}

Indicates significance at $* * \mathrm{p}<0.001, * \mathrm{p}<0.05$ probability level, ns, indicates non significance. $* *=$ highly significant, $*=$ significant, ns $=$ non- significant

Identified farmers' varieties $30-50$ years old in the study area

In the study area respondents listed 35 threatened farmers' varieties in their vernacular names and the listed 35 varieties' vernacular name is different from one area to another area. In addition to this, the listed 35 varieties were not found in all 16 Kebeles (the smallest administration structure of government) survey areas.

The distribution of varieties was 2-8 varieties in one kebeles. This uneven distribution in the study area has its own negative effect to measure the frequency of respondents in order to identify the most threatened varieties. Some species like "Gomor, Buhere, Ahiyo, Mekole, Dawulle, Dinbito and Gora-gomej" are found in one kebeles only.

However, the result of this study revealed that, all 35 listed farmers' varieties of tef were in the situation of under threatening and its frequency was 1 to 155 (Table 7) (Figure 3\&4). Especially; "Key tef (Dabo tef), Ancharo, Murie, Emblabish and Fesho" are highly eroded.Based on the significance of the ANOVA, test of significance difference of mean values of 35 listed threatened farmers' variety of tef at least 30-50 years old in the area was employed (Table 6). It was observed that varieties were significantly $(\mathrm{p}<0.05)$ different between and within group from each other.

Decriptive statistical analysis of threatened farmers' variety of tef at least 30-50 years old in the area shows that, they are slightly skewned to the left. As the result revealed in (Table 3), mean is less than median $($ mean $=30.31$ and median $=34.00)$ and the extent of score distribution in histogram graph is tell us slightly deviates from perfect symmetry.

As the graphic presentation of identified threatened farmers' varieties of tef revealed that, the lowest and the highest frequency was 1 to 155 respectively. From 332 respondent's frequencies of 41 to 155 were eight varieties of tef are more expose to erosion.

\section{Effects of factors contributed for the erosion of farmers' varieties of Tef}

As the survey result shows that, $76.5 \%$ participants mentioned the factor for the erosion of land race of tef cultivar was introduction 
of improved varieties. The second and the third causes were Climate change and bad weather like drought, floods etc, Logging problem $\&$ introduction of improved varieties having value $9 \%$ \& $4.8 \%$ respectively. In the interview and discussion time reduction of productivity and the combined effect of reduction of productivity \& introduction of improved varieties effects were given emphasis by participants only $5.7 \%$ as a factor for the erosion. The other two factors which were discussed in the study have each $0.3 \%$ share from the total results as a cause of erosion of land race of tef.

Similarly studies show that, diversified local food production systems are under threat, including the local knowledge, culture, and skills of farmers. ${ }^{24-28}$ The major factors that have contributed to the loss of indigenous crops include: introduction of exotic species, habitat destruction, land use change, population pressure, selection by farmers and climate change. ${ }^{24,25,28}$ Besides, many traditional crops have been abandoned due to intensification of farming systems. ${ }^{27,28}$ The survey results are presented here below in (Table 8) (Figure 5).

Decriptive statistical analysis of factors render for the erosion of land race tef variety shows that, they are almost skewned to the right. As the result revealed in (Table 3), mean is grater than median (mean $=3.17$, median $=3$ and mode $=3$ ) and the extent of score distribution in histogram graph is tell us slightly deviates from perfect symmetry.

Table 7 List of identified threatened farmers' variety of tef at least 30-50 years old in the area named \& ranked by respondents

\begin{tabular}{|c|c|c|c|}
\hline S.no & $\begin{array}{l}\text { vernacular names of } \\
\text { cultivars/land race }\end{array}$ & frequency & Percent (\%) \\
\hline I & Key tef(Dabo tef) & 155 & 46.68 \\
\hline 2 & Ancharo & 110 & 33.13 \\
\hline 3 & Murie & 108 & 32.53 \\
\hline 4 & Emblabish & 96 & 28.91 \\
\hline 5 & Fesho & 70 & 21.08 \\
\hline 6 & Jige & 52 & 15.66 \\
\hline 7 & Abishlmine & 41 & 12.34 \\
\hline 8 & Busoye & 31 & 9.33 \\
\hline 9 & Agezew & 31 & 9.33 \\
\hline 10 & Dz-0I-196/354 & 31 & 9.3 \\
\hline II & Bilito & 30 & 9.03 \\
\hline 12 & Sayint & 29 & 8.73 \\
\hline 13 & Gorad/Goradie & 28 & 8.43 \\
\hline 14 & Fenkil & 28 & 8.41 \\
\hline 15 & Bunign & 24 & 7.22 \\
\hline 16 & Goche & 24 & 7.22 \\
\hline 17 & Enat Dabo & 23 & 6.92 \\
\hline 18 & Mere & 23 & 6.92 \\
\hline 19 & Deke & 21 & 6.32 \\
\hline 20 & Bake & 16 & 4.81 \\
\hline 21 & Durssa & 15 & 4.51 \\
\hline 22 & Kezez & 15 & 4.51 \\
\hline 23 & Siyit & 14 & 4.21 \\
\hline 24 & Gomid & 14 & 4.21 \\
\hline 25 & Kuakurie & 12 & 3.61 \\
\hline 26 & Zige & 11 & 3.31 \\
\hline 27 & Wuhakida & 10 & 3.01 \\
\hline 28 & Ashefetihegn & 9 & 2.71 \\
\hline 29 & Gomor & 9 & 2.71 \\
\hline 30 & Buhere & 9 & 2.71 \\
\hline 31 & Ahiyo & 8 & 2.4 \\
\hline 32 & Mekole & 3 & 0.9 \\
\hline 33 & Dawulle & I & 0.3 \\
\hline 34 & Dinbito & I & 0.3 \\
\hline \multirow[t]{2}{*}{35} & Goragomej & I & 0.3 \\
\hline & Total & & 332 \\
\hline
\end{tabular}


Table 8 Factors that render for the erosion/loss of varieties and respondents result

\begin{tabular}{|c|c|c|c|c|}
\hline Variable & Frequency & Percent & Valid percent & Cumulative percent \\
\hline Invasive alien plant species & 6 & 1.8 & 1.8 & 1.8 \\
\hline Climate change and bad weather: drought, floods etc & 30 & 9 & 9 & 10.8 \\
\hline Farming/cultivation systems & 3 & 0.9 & 0.9 & 11.7 \\
\hline Introduction of improved varieties & 254 & 76.5 & 76.5 & 88.3 \\
\hline logging problem \& introduction of improved varieties & 16 & 4.8 & 4.8 & 93.1 \\
\hline Introduction of improved varieties and other factors (weed...) & 1 & 0.3 & 0.3 & 93.4 \\
\hline Farming/cultivation system and logging problem & I & 0.3 & 0.3 & 93.7 \\
\hline Reduction of productivity \& introduction of improved varieties & 12 & 3.6 & 3.6 & 97.3 \\
\hline Reduction of productivity & 7 & 2.1 & 2.1 & 99.4 \\
\hline Do not Know & 2 & 0.6 & 0.6 & 100 \\
\hline Total & 332 & 100 & 100 & \\
\hline
\end{tabular}

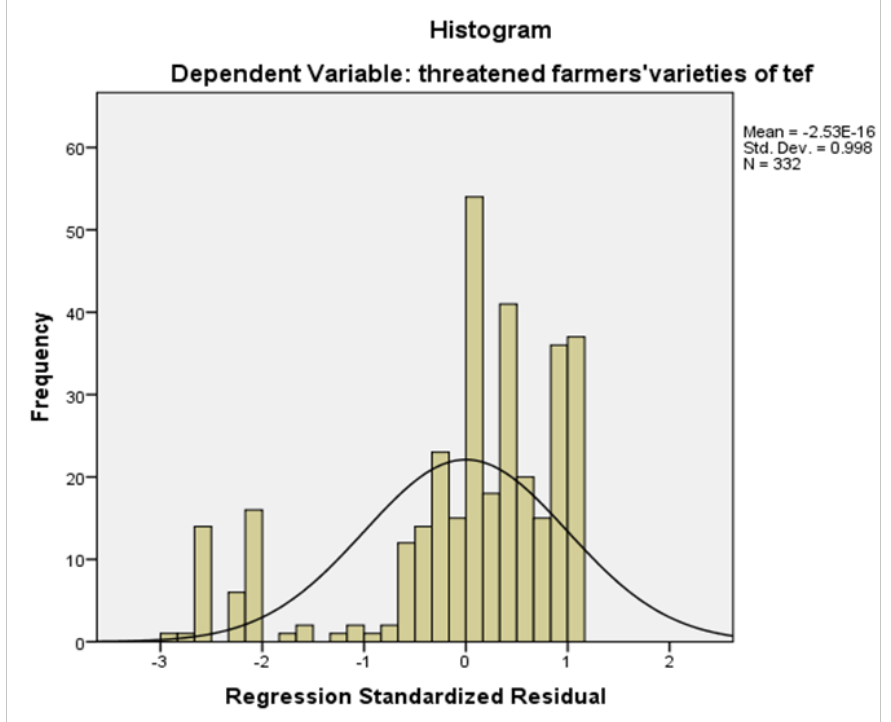

Figure 3 Graphic presentation of threatened farmers' varieties (land race) tef.

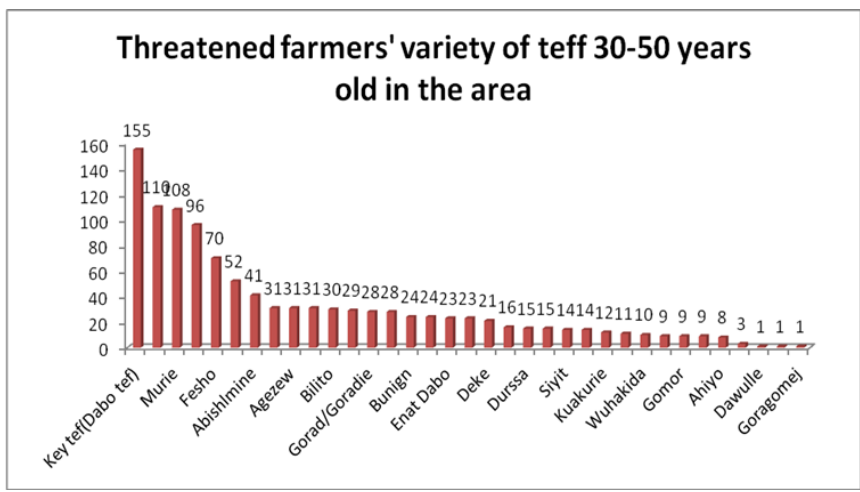

Figure 4 Frequency of graphic presentation on the identified threatened land race tef varieties in the study area.

\section{Constraint or the challenge of conservation of farmers' varieties on farm land}

The study results revealed that, $319(96.1 \%)$ respondents said no conservation work and awareness or training given on the advantage of conservation of farmers' varieties (land race) in their area. On the other hand $13(3.9 \%)$ respondents are get awareness and practice conservation work of farmers' varieties on their farm sees (Table 9).

These show that land race or farmers' varieties are intentionally ignored and the existing extension system did not give attention and systematically it's out of production. The other worst condition is the associated very important traditional knowledge; perceptions regarding their existence would be lost.

Furthermore, results of the survey show that, on average, two of the seven different varieties currently cultivated in the villages face being abandoned and lost. Nevertheless, farmers repeatedly stressed during the individual and group interviews that lost varieties had strongly preferred plant traits, such as flavor, high yield potential in special area/land and superior grain quality for food, medicinal value and storage.

Also, it has been observed that production systems evolving in favors of improved varieties of "Quncho" and "Etsub" lead to a reduction of land race tef varieties of "Key tef (Dabo tef), Ancharo, Murie, Emblabish and Fesho" in the study area. There was also similar study on the farmers' preference of varieties (traits) and the impact of favoring of improved varieties. ${ }^{29}$

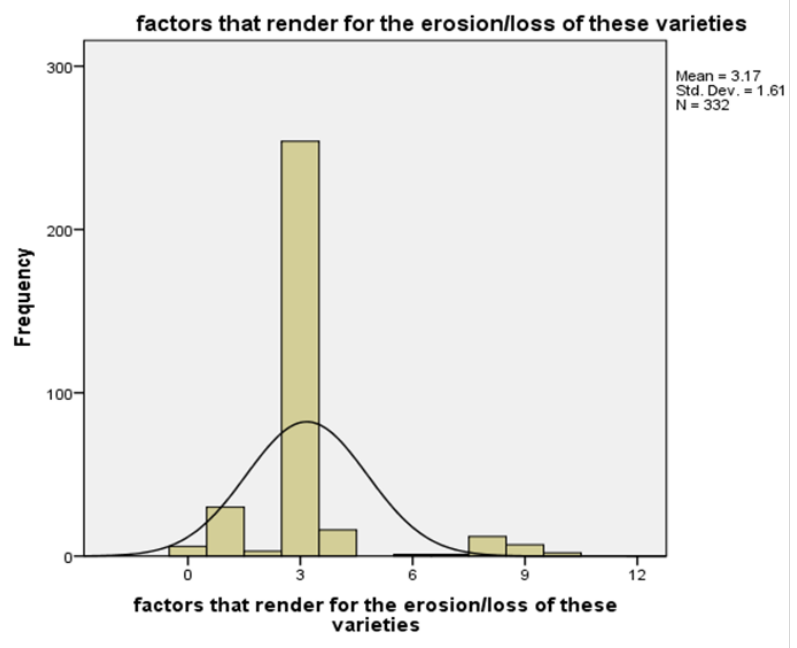

Figure $\mathbf{5}$ Graphic presentation of factors render for the erosion of land race tef variety. 
Due to rapid changes happening in the socio-economic sphere of traditional farming systems and their practitioners, traditional community-based agro-biodiversity management practices have been disappearing at an alarming rate in the last three decades.

On-farm conservation of useful crops and varieties is very important as these crops and their cropping systems play a vital role in fulfilling the food, nutritional and other requirements of those living in marginal environments. In the face of changing climatic conditions, these crops and varieties, and their associated traditional knowledge, could play a vital role in enhancing resilience among rural communities and enabling them to adapt to climate change..$^{30,31}$

Correlation and regression among factors that render for the erosion of land race of tef listed and threatened variety at least $\mathbf{3 0 - 5 0}$ years old in the area

Based on the statistical procedure mentioned by Pearson Correlation, correlation between factors for erosion and listed farmers' varieties at least 30-50 years old in the area was analyzed and the results are presented in (Table 10). Factors that render for the erosion/ loss of these varieties was also highly significantly and negatively correlated with listed (0.00) considered in this study.

\section{Statistical significance of the model}

The F-value or ratio in the ANOVA (Table 11) tests whether the overall regression model is a good fit for the data. The table shows that the independent variables statistically significantly predict the dependent variable, $\mathrm{F}=19.720, \mathrm{p}(0.001)<0.05$, that is, the regression model is a good fit of the data.

We can conclude "Yes, the independent variables reliably predict the dependent variable". You could say that factors that render for the erosion of land race of tef can be used to reliably predict a list of threatened farmers' variety of tef at least 30-50 years old in the area (the dependent variable) (Figure 6).

Table 9 Practice or get awareness of farmers to conserve land race of tef in their farm

\begin{tabular}{llllll}
\hline & & Frequency & Percent & Valid percent & Cumulative percent \\
\hline Valid & yes & 13 & 3.9 & 3.9 & 3.9 \\
& No & 319 & 96.1 & 96.1 & 100 \\
& Total & 332 & 100 & 100 &
\end{tabular}

Table 10 Correlation analysis on factors that render for the erosion of land race of tef and listed and threatened variety at least 30-50 years old in the area (Pearson correlation Sig. (2-tailed)

\begin{tabular}{|c|c|c|c|c|}
\hline & & $\begin{array}{l}\text { factors that render } \\
\text { for the erosion/loss } \\
\text { of these varieties }\end{array}$ & $\begin{array}{l}\text { List threatened } \\
\text { farmers' variety of } \\
\text { teff at least } 30-50 \\
\text { years old in the area }\end{array}$ & $\begin{array}{l}\text { Lost or threatened } \\
\text { variety at least } \\
30-50 \text { years old in } \\
\text { the area }\end{array}$ \\
\hline \multirow[t]{3}{*}{$\begin{array}{l}\text { factors that render for the erosion/loss of } \\
\text { these varieties }\end{array}$} & Pearson Correlation & I & & \\
\hline & Sig. (2-tailed) & & & \\
\hline & $\mathrm{N}$ & 332 & & \\
\hline \multirow[t]{3}{*}{$\begin{array}{l}\text { List threatened farmers' variety of teff at least } \\
30-50 \text { years old in the area }\end{array}$} & Pearson Correlation & $-0.237 * *$ & I & \\
\hline & Sig. (2-tailed) & 0 & & \\
\hline & $\mathrm{N}$ & 332 & 332 & \\
\hline \multirow[t]{3}{*}{$\begin{array}{l}\text { Lost or threatened variety at least } 30-50 \text { years } \\
\text { old in the area }\end{array}$} & Pearson Correlation & -0.074 & -0.041 & I \\
\hline & Sig. (2-tailed) & 0.182 & 0.457 & \\
\hline & $\mathrm{N}$ & 332 & 332 & 332 \\
\hline
\end{tabular}

**. Correlation is significant at the 0.01 level (2-tailed).

Table I I Regression analysis on factors that render for the erosion of land race of tef and listed and threatened variety at least $30-50$ years old in the area

\begin{tabular}{lllllll}
\hline Model & & Sum of squares & df & Mean square & F & Sig. \\
\hline I & Regression & 2467.163 & I & 2467.163 & 19.72 & $.000 \mathrm{~b}$ \\
& Residual & 41285.499 & 330 & 125.108 & & \\
& Total & 43752.663 & 331 & & & \\
\hline
\end{tabular}

ANOVA $^{\mathrm{a}}$

a. Dependent Variable: List threatened farmers' variety of tef at least 30-50 years old in the area

b. Predictors: (Constant), factors that render for the erosion/loss of these varieties 
Normal P.P Plot of Regression Standardized Residual

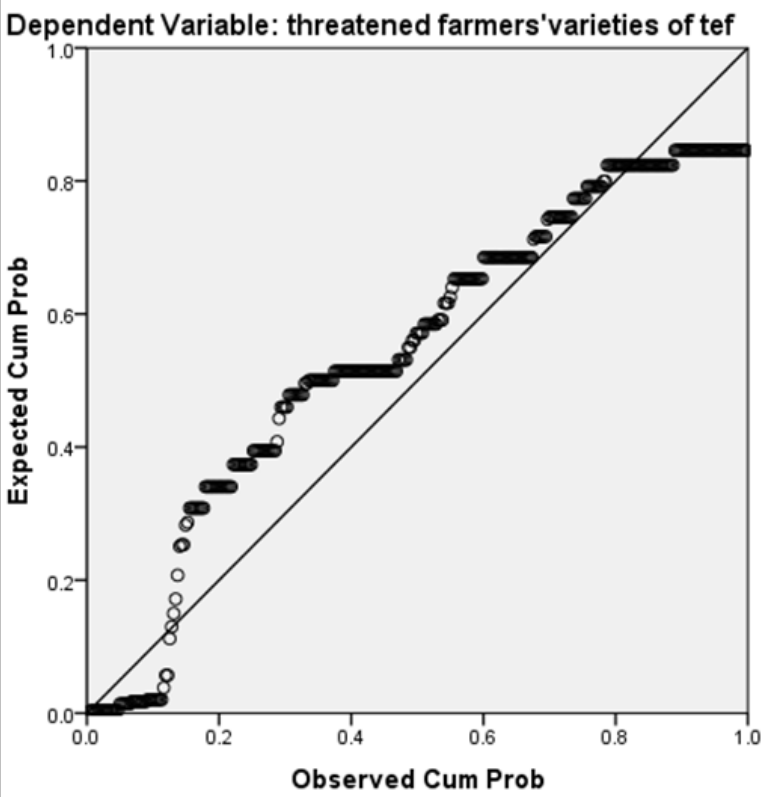

Figure 6 Regression result of factors that render for the erosion of land race of tef and dependent variable of threatened farmers' variety of teff at least $30-50$ years old in the area.

\section{Conclusions and the way forward}

Although Ethiopia is the center of origin and diversity of tef and the current expansion of improved tef varieties particularly "Quncho and Etsub" in many area of the country became a threat to genetic erosion and the situation is very alarming. Even though the situation is worst, still the policy maker, governmental and nongovernmental organization is giving less attention. Some traditional tef varieties have declined and some have even disappeared. In situ conservation measures such as preserved seeds, on farm planted crops are very important methods for conserving local agro-biodiversity hence need to be enhanced in study area.

The reveal of 35 farmers' varieties of tef, 30-50 years old in the study area were identified as under threatened; especially; namely called in local language (vernacular name) "Key tef (Dabo tef), Ancharo, Murie, Emblabish and Fesho" are highly eroded.76.5\% participants were responded that the main factor for the erosion of land race of tef cultivar was introduction of improved varieties. Next to this, the second and the third causes for erosion of land race were Climate change and bad weather (drought, floods etc), logging problem \& introduction of improved varieties $9 \%$ and $4.8 \%$ respectively.

Therefore, from the forgoing results active community participation in integrated agro-biodiversity resource management, facilitation of innovative ideas of change agencies and favorable state policy support are essential elements in on-farm conservation and sustainable use. This conservation strategy should emphasize farmer's responsibility for the maintenance and sustainable utilization of diversity. Such partnership is needed to effectively handle the issues related to conservation, food and nutritional security, and climate change.

Thus, in future I recommend that conservation of agro-biodiversity, sustainable protection measures based on local communities should be considered and adopted and develop packages for farmers' varieties and promoting awareness creation and on farm conservation practice in regular existing extension system.

\section{Acknowledgements}

First of all, I would like to thank God for being with me in all aspects of my journey and I would like to extend my appreciation and sincere thanks to Woreda (District) Agriculture office and Kebele Development Agent staff especially Crop development staff and experts arrange and organizing communities and community leaders to make my survey easy and complete in given schedule.

\section{Conflicts of interest}

Authors declare no conflict of interest exists.

\section{References}

1. Mulat D. Agricultural technology, economic viability and poverty alleviation in ethiopia, paper presented to the agricultural transformation policy workshop, Kenya. 1999.

2. Padulosi S, Dulloo E. Towards a viable system for monitoring agro biodiversity on-farm: a proposed new approach for Red Listing of cultivated plant species. In: Padulosi S, Bergamini N, et al. editors. On- Farm conservation of neglected and underutilized species: status, trends and novel approaches to cope with climate change. Proceedings of the International Conference, Frankfurt, 14-16 June 2011. Bioversity International. Pp. 2012;171-197.

3. Vavilov I. The origin, variation, immunity and breeding of cultivated plants. Translated from the Russian by K. S. Chester, The Ronald Press Co, New York, USA. 1951.

4. Demisse Abebe. In-situ conservation: the Ethiopian experience. ILEIA Newsletter, December, IBCR, A.A., Ethiopia. 1999.

5. Endeshaw Bekele, Lester RN. Biochemical assessment of the relationships of Eragrostis tef (Zucc.) Trotter with some wild Eragrostis species (gramineae). Ann Bot. 1981;48:717-725.

6. Tadesse Ebba. Tef (Eragrostis tef) cultivars; Morphology and classification. Part II. Expt.Sta. Bull. No. 66. Addis Ababa University, College of Agriculture. Dire Dawa, Ethiopia. 1975.

7. Pankhurst S. Flora of Ethiopia, volume 7, the national herbarium, biology department, science faculty, Addis Ababa, University, Ethiopia and the department of systematic botany, Uppsala University, Sweden, 1995

8. CSA. Agricultural Sample Survey for 2013/14. Statistical bulletin 532. Addis Ababa, Ethiopia: Central Statistical Agency. 2014.

9. Seyfu Ketema. Tef, (Eragrostis tef): Breeding, genetic resources, agronomy, utilization and role in Ethiopian agriculture. Institute of Agricultural Research, Addis Ababa, Ethiopia. 1993.

10. Seyfu Ketema. Tef (Eragrostis tef (Zucc)Trotter). Promoting the conservation and use of under honolog and neglected crops. 12. The institute of plant genetics and crop plant research. Gatersleben/ International Plant Genetic Resources Institute). Rome, Italy. 1997.

11. Spaenij-Dekking L, Kooy-Winkelaar Y, Koning F. The Ethiopian cereal tef in celiac disease. $N$ Engl J Med. 2005;353:1748-1749.

12. Alaunyte I, Stojceska V, Plunkett A, et al. Improving the quality of nutrient-rich Teff (Eragrostistef) breads by combination of enzymes in straight dough and sourdough bread making. J Cereal Sci. 2012;55:2230 .

13. FAO. Fact sheet: What is agro-biodivesity? Training and Manual, Building a Gender. 2004. 
14. FAO. The state of the world's animal genetic resources for food and agriculture. Food and agricultural Organization of the United Nation, Rome. 2007

15. Melaku Worede. Establishing a community seed supply system: Community seed bank complex in Africa. 2011;360-377.

16. Solomon Chanyalew, Kebebew Assefa, Gizaw Metaferia. Achievements and Prospects of Tef Improvement, Proceedings of the Second International Workshop, Debre Zeit, Ethiopia. 2011.

17. CSA. Central Statistics Agency based, the 2017.

18. Alexiades MN. Collecting ethnobotanical data: An introduction to basic concepts and techniques: In: Selected guidelines for ethno botanical research: A field manual. The New York Botanical Garden, Bronx, New York. 1996.

19. Martin GJ. Ethnobotany: A method manual. Royal botanical garden, Champman and Hall, Kew, Londan. 1995.

20. Shanin T. Defining peasants blackwell publisher accessed on 19April, 2012

21. Kargıoğlu M, Cenkci S, Serteser A, et al. Traditional uses of wild plants in the middle Aegean region of Turkey. Human Ecology. 2010;38(3):429-450.

22. Guendel S. Building on gender, agrobiodiversity and local knowledge FAO LinKS project. FAO, Rome, Italy. 2005

23. Jarvis DI, Padoch C, Cooper HD. Biodiversity, agriculture and ecosystem services.pp. 1-12, in: DI Jarvis, C Padoch, et al. editors. Managing biodiversity in agricultural ecosystems. Published for Bioversity International by Columbia University Press, New York, USA. 2007.
24. De Boef WS, MH Thijssen. Participatory tools working with crops, varieties and seeds. A guide for professionals applying participatory approaches in agrobiodiversity management, plant breeding and seed sector development. Wageningen, Wageningen International. 2007.

25. FAO. FAO/WFP crop and food security assessment mission to Ethiopia. Food and agriculture organization of the United Nations, Rome, Italy. 2010

26. FAO. Training Manual: Building on gender, agro biodiversity and local knowledge. Food and Agriculture Organization, Rome. 2005.

27. Prescott-Allen RC, Prescott-Allen. How many plants feed the world? Conservation Biology. 1990;4:365-374

28. Smolders H. Editor of enhancing farmers' role in crop development: framework information for participatory plant breeding in farmers field schools. PEDIGREA publication. Center for Genetic Resources, Wageningen, The Netherlands. 2006.

29. Delaunay S, Tescar RP, Oualbéogo A, et al. La culture du coton ne bouleverse pas les échanges traditionnels de semences de sorgho [Growing cotton does not disrupt traditional sorghum seed exchange]. Cahiers Agricultures. 2008;17(2):189-194.

30. Bhag Mal, Padulosi S, Bala Ravi S. Minor millets in south asia: learnings from IFAD-NUS Project in India and Nepal. Bioversity International, Rome, Italy, and the M.S. Swaminathan Research Foundation, Chennai, India. 185. 2010.

31. UNDP. UNDP assistance in the fifth country program to the agricultural sector. 2002 